(c) Group of authors, 2021

UDC 618.5-089.888.61:616-002

DOI - https://doi.org/10.14300/mnnc.2021.16050

ISSN - 2073-8137

\title{
FOURNIER GANGRENE IN PUERPERAS AFTER CESAREAN SECTION
}

\author{
Ryzhkov V. V. ', Gasparyan S. A. ', Derevyanko T. I. ', Kopylov A. V. ', \\ Papikova K. A. ${ }^{1}$, Pydra A. R. ${ }^{1}$, Pivovarova N. I. ${ }^{2}$, Gordeeva L. P. ${ }^{2}$ \\ ${ }^{1}$ Stavropol State Medical University, Russian Federation \\ ${ }^{2}$ City clinical hospital of the emergency medical services, Stavropol, Russian Federation
}

\section{ГАНГРЕНА ФУРНЬЕ У РОАИАЬНИЦЫ ПОСАЕ ОПЕРАЦИИ КЕСАРЕВА СЕЧЕНИЯ}

\author{
В. В. Рыжков ', С. А. Гаспарян ', Т. И. Аеревянко ', А. В. Копылов ', \\ К. А. Папикова ${ }^{1}$, А. Р. ПыАра ${ }^{1}$, Н. И. Пивоварова ${ }^{2}$, А. П. ГорАеева ${ }^{2}$ \\ ${ }^{1}$ Ставропольский госуАарственный меАицинский университет, \\ Российская ФеАерация \\ 2 ГороАская кАиническая больница скорой меАицинской помощи, Ставрополь, \\ Российская ФеАерация
}

Fournier gangrene is a form of necrotizing fasciitis that mainly affects men suffering from immunodeficiency after surgeries of the genitals and perineum. Literature data on the occurrence of this complication in women are rare, and there are no data in obstetric practice. Herein, we present a clinical case of severe sepsis with an unfavorable outcome owing to anterior abdominal wall phlegmon (Fournier phlegmon) in a puerperal woman after cesarean section.

\footnotetext{
Keywords: cesarean section, Fournier gangrene, sepsis
}

В современных условиях гангрена Фурнье (эпифасциальный некроз) трактуется как специфическая форма некротизирующего фасциита, поражающая преимущественно мужчин, страдающих иммунодефицитом, после операций на половых органах и промежности. Данные литературы о возможности наличия этого осложнения у женщин единичные, а в акушерской практике отсутствуют. Описан клинический случай тяжелого сепсиса с неблагоприятным исходом вследствие флегмоны передней брюшной стенки (флегмона Фурнье) у родильницы после операции кесарева сечения.

Ключевые слова: операция кесарево сечение, гангрена Фурнье, сепсис

For citation: Ryzhkov V. V., Gasparyan S. A., Derevyanko T. I., Kopylov A. V., Papikova K. A., Pydra A. R., Pivovarova N. I., Gordeeva L. P. FOURNIER GANGRENE IN PUERPERAS AFTER CESAREAN SECTION. Medical News of North Caucasus. 2021;16(2):212-215. DOI - https://doi.org/10.14300/mnnc.2021.16050

Для цитирования: Рыжков В. В., Гаспарян С. А., Деревянко Т. И., Копылов А. В., Папикова К. А., Пыдра А. Р., Пивоварова Н. И., Гордеева Л. П. ГАНГРЕНА ФУРНЬЕ У РОДИЛЬНИЦЫ ПОСЛЕ ОПЕРАЦИИ КЕСАРЕВА СЕЧЕНИЯ. Медицинский вестник Северного Кавказа. 2021;16(2):212-215. DOI - https://doi.org/10.14300/mnnc.2021.16050

$$
F^{\circ}
$$
ournier gangrene (epifascial necrosis) is a specific form of necrotizing fasciitis that affects patients of both sexes and of any age. However, it is mainly observed in men suffering from immunodeficiency $[1,2]$, especially in those with injuries of the genitals and perineum. Cases of the development of Fournier gangrene after piercing and injection of drugs into the veins of the penis and cavernous bodies have been described [3, 4]. Streptococcus, Staphylococcus, Escherichia coli, and microbial associations involving anaerobic bacteria play a significant role as infectious agents [5-7]. The disease is characterized by the vastness and high rate of lesion spread; total necrosis can develop up to the anterior abdominal wall and even further into the axillary areas as well as the inner surface of the thighs. This is owing to the mixed nature of the infection, involving the release of enzymes and toxins by microbes; this causes high pathogenic- ity and thrombosis in the vessels, resulting in tissue necrosis. Owing to tissue hypoxia, anaerobes that produce hyaluronidase, lecithinase, and collagenase begin to actively multiply. These favorable conditions aid the microorganisms in rapidly overcoming interstitial and fascial barriers $[8,9]$. The mortality rate is extremely high and can exceed $40 \%$ [10]. Nevertheless, successful treatment of these patients has been previously reported [11-14].

Reports of Fournier gangrene in women are rare [15], and there are no data in obstetric practice. Pregnancy itself, particularly its pathological course, contributes to the development of immunodeficiency [16, 17]. Surgical interventions on the perineum (i.e., episiotomies, vaginal tissues, and perineum restoration after traumatic childbirth); surgical delivery, including cesarean section; and damage to nearby organs, specifically the urethra, bladder, and rectum, all contribute to the parturient occurrence of this disease. 
Clinical case. A 25-year-old primigravid from Stavropol had been observed by obstetrician-gynecologists since 5-6 weeks of gestation. She had a height of $170 \mathrm{~cm}$, body weight of $46 \mathrm{~kg}$, and body mass index of 17 . Her examination revealed endocervicitis, $E$. coli growth in the cultures of samples from the cervical canal, and the presence of leptotrichia and diphteroids on vaginal smears. Antibacterial treatment was prescribed. At the $17^{\text {th }}$ week of gestation, E. coli growth $\left(10^{4}\right)$ was detected in the urine. There was severe lymphocytopenia with threat of pregnancy termination; thus, she was repeatedly hospitalized and was administered multicomponent therapy, including progesterone derivatives. After consultation with a therapist, the patient was diagnosed with heart connective tissue dysplasia syndrome with mitral valve prolapse of moderate hemodynamic significance. The pregnancy was complicated by moderate preeclampsia, leading to hospitalization in the pathological pregnancy department of a multispeciality hospital at the $37^{\text {th }}$ week of gestation; preeclampsia treatment was initiated and preparations for childbirth were begun. Owing to premature discharge of amniotic fluid, she was transferred to the maternity unit. Regular birth activity developed, which later became uncoordinated. The waterless period was $9 \mathrm{~h}$ and $38 \mathrm{~min}$. A live, full-term female child was delivered via emergency cesarean section (Stark method). The baby weighed $3260 \mathrm{~g}$, was $51 \mathrm{~cm}$ long, and had an Apgar score of 8-9 points. The mother experienced blood loss of $800.0 \mathrm{ml}(1.6 \%$ of body weight and $20 \%$ of blood volume). Preventive measures were taken for purulent-septic complications during the operation and blood transfusion.

The placenta was $16 \times 16 \times 1.0 \mathrm{~cm}$ in size, $256 \mathrm{~cm}^{3}$ in volume, and $580 \mathrm{~g}$ in weight. The placental-fetal mass index was 0.18 (normal: 0.14-0.15). The placenta was fleshy, dark maroon with a gray surface. Histopathological examination revealed serous choriodeciduitis.

The postoperative period was complicated by acute purulent endometritis, salpingoophoritis, peritoneal sepsis, and septic shock. On the $2^{\text {nd }}$ day after the cesarean section, hysterectomy with tubes, sanitation, and drainage of the abdominal cavity were performed. In the abdominal cavity, there was a $200-\mathrm{ml}$ foul-smelling cloudy effusion containing fibrin. Upon incision, the uterine muscle was noted to have the color of boiled meat; the serous cover was gray, and the tubes were hyperemic and edematous. The uterus had a putrid smell. Intensive antibacterial therapy, infusion therapy, and inotropic support were performed. The vital signs stabilized and the symptoms of peritonitis subsided. Subsequently, the putrefactive phlegmon of the anterior abdominal wall rapidly spread both up and down from the transverse incision line of the anterior abdominal wall, causing total necrosis and further spread to the pubis and thighs (Fig. 1).

Because of the progression of the putrefactivenecrotic process, repeated step-by-step necrectomies with a wide capture of healthy tissues were performed, with daily sanitization of the wound surface using antiseptic solutions as well as intensive therapy for multiple organ failure combined with extracorporeal detoxification methods in a ventilator. Unfortunately, on the $14^{\text {th }}$ day post-delivery, with increasing symptoms of multiple organ failure, the mother died. Bacteriological examination of the anterior abdominal wall wound discharge revealed a continuous growth of hemolytic $E$. coli; clostridium was not detected. The child was diagnosed with intrauterine pneumonia, which was effectively treated in the neonatal intensive care unit.

On the basis of the obtained clinical and pathohistological data of the placenta study, the ascending path of fetus infection should be considered.

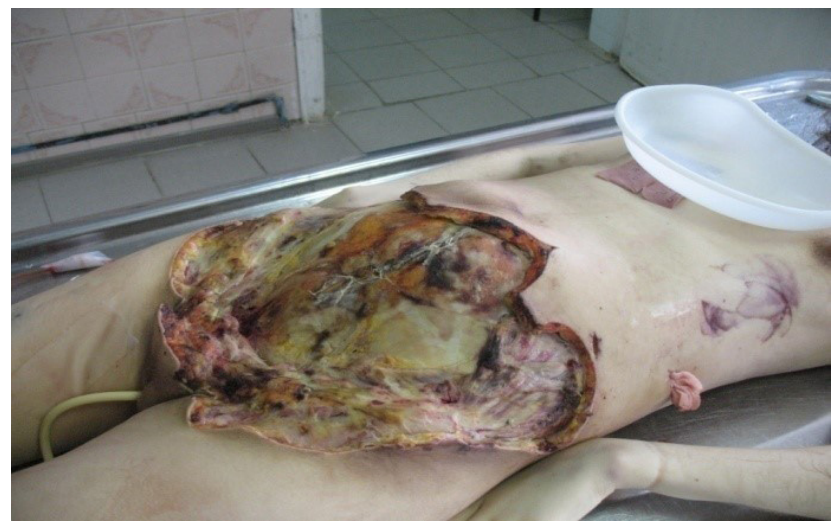

Fig. 1. Total necrosis of the anterior abdominal wall

After a pathologic-anatomical autopsy followed by microscopic examination of histological preparations of all vital organs, similar changes were noted: necrosis, dystrophy, microcirculation disorders in the form of capillary dilation, full blood, leukocyte stasis in blood, thrombosis, and hemorrhages. Signs of respiratory distress syndrome were also noted in the lungs.

Purulent necrotic endometritis and metrothrombophlebitis were observed in the uterus. Parametritis was also observed. Acute purulent salpingitis was observed. Vascular thrombosis, vasculitis, and leukocyte infiltrates were noted in the ovaries.

There was no free fluid in the abdominal cavity. The serous intestinal membranes and the abdominal layers were smooth and shiny. The pelvis was clear.

There were findings of leukocyte infiltration, vasculitis, hemorrhages, necrosis of muscle fibers, and microabscesses in the tissues of the anterior abdominal wall (dermis, subcutaneous fat, and muscles) (Fig. 2).

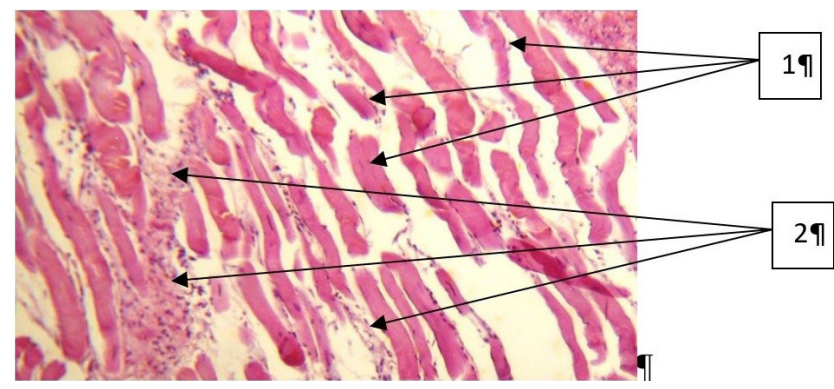

Fig. 2. Anterior abdominal wall. Necrosis of muscle fibers (1). Microabscesses (2). Magnification 40. Hematoxylin-eosin staining

A bacteriological study of blood from the heart revealed an increase in the levels of Enterobacteriaceae with a predominance of $E$. coli.

The patient's main cause of death was severe sepsis and multiple organ failure. Infection foci were found in the anterior abdominal wall (total necrosis, resulting in Fournier gangrene) and uterus (purulent necrotic endometritis). Removal of the uterus led to the elimination of peritonitis. Repeated step-by-step necrectomies were ineffective owing to the extremely rapid progression of the necrosis of the anterior abdominal wall (purulent necrotic fasciitis, myositis, and skin and subcutaneous fat gangrene).

Prevention, early detection, and treatment of Fournier gangrene are all critical in disease outcomes.

Initially, the clinical picture resembled cellulitis. There was swelling of the skin, hyperemia, local soreness, 
increased body temperature, signs of intoxication, weakness, and muscle and joint pain. The edema rapidly increased, crepitation developed, and the skin hyperemia was replaced by the appearance of purplish-black foci, indicating pronounced tissue ischemia. The wound had a putrid smell. Necrosis and tissue rejection occurred. To confirm the diagnosis, culture studies of the blood, urine, and wound discharge were performed. Arterial blood gas was evaluated. Radiological evaluation of the abdominal cavity was also performed. Clinical tests of blood, urine, coagulation, biochemical tests, and serum electrolytes were conducted [18-20].

In maternity hospitals, preventive measures for Fournier gangrene aim to reduce maternal birth trauma and surgical obstetric interventions in obstetrics, with a focus on compliance with personal hygiene. Perioperative prevention of purulent-septic diseases is mandatory, particularly in high-risk groups, including pregnant women with chronic infection foci, diabetes mellitus, and other extragenital diseases [21-23]. Before delivery, it is extremely important to sanitize the infection foci in the mother's body, particularly those in the urogenital system and gastrointestinal tract, normalize the microflora of the vagina and intestines, and restore the acidic environment in the vagina.

Conclusions. The treatment of Fournier's gangrene should be based on urgent surgical excision of necrotic tissues with the drainage of abscesses and phlegmon alongside powerful antibacterial and detoxification therapy, including methods of extracorporeal detoxification.

Disclosures: The authors declare no conflict of interest.

\section{References}

1. Urology: National guidance. Ed. N. A. Lopatkin. Moscow: GEOTAR-Media Publ. 2009;582-583.

2. Ephimenko M. A., Privolnev V. V. Fournier's gangrene. Clinical Microbiology and Antimicrobial Chemotherapy. 2008;10(1):34-42.

3. Ekelius L., Bjorkman H., Kalin M., Fohlman J. Fournier's gangrene after genital piersing. Scand. J. Infect. Dis. 2004;36:610-612. https://doi.org/10.1080/00365540410017086

4. Mouraviev V. B., Pautier S. E., Hauman W. P. Fournier's gangrene following penile self-injection with cocaine. Scand. J. Urol. Nephrol. 2002;36:31:7-8 https://doi.org/10.1080/003655902320248326

5. Yegorkin M. A Fournie's disease and anaerobic paraproctitis - different clinical forms of same pathological process? News of Coloproctology. - Novosti koloproktologii. 2012;22(4):66-72.

6. Amr A., Sajad S. Fournier's gangrene - Case report and a brief review. Journal of Pakistan Association of Dermatologists. 2015;25:44-51.

7. Tahmaz L., Erdemir F., Kibar V., Cosar Ah., Yalcyn O. Fournier's gangrene: report of thirty-three cases and a review of the literature. Int. Urol. 2006;13(7):960-967. https://doi.org/10.1111/j.1442-2042.2006.01448.x

8. Thwaini A., Khan A., Malik A. Cherian J., Barua J. [et al.] Fournier's gangrene and it's emergency management. Postgraduate Medical Journal. 2006;82:516-519. https://doi.org/10.1136/pgmj.2005.042069

9. Grinev M. V., Soroka I. V., Grinev K. M. Fournier's Gangrene - a model of necrotizing fasciitis (Clinical and pathogenetic aspects). Urologiya. 2007;6:69-75.

10. Unal B., Kocer B., Ozel E., Boskurt B., Yildirim O. [et al.] Fournier Gangrene Approaches to Diagnosis and Treatment. Saudi Med. 2006;27:1038-1043.

11. Chinikov M. A., Tkachenko Yu. N., Bagdasaryan A. G., Dobrovolskii S. R. Successful treatment of patient with fournier's phlegmon. Pirogov Russian Journal of Surgery. Khirurgiya. Zhurnal im. N.I. Pirogova. 2007;11:53-54.

12. Yanar H., Taviloglu K., Ertekin C., Guloglu R., Zorba U. [et al.] Fournier's gangrene: risk factors and strategies for management. World J. Surg. 2006;30:1750-1754 https://doi.org/10.1007/s00268-005-0777-3

13. Bordakov P V. Bordakov V. N., Gain Yu. M., Shakhrai S. V., Gain M. Yu. Fournier's gangrene: clinic, diagnos- tics, treatment. Wounds and wound infections. The prof. B. M. Kostyuchenok journal/ 2017;4(1):14-23.

https://doi.org/10.17650/2408-9613-2017-4-1-14-23

14. Dzhamalov F. G., Nabieva E. V., Abdullayev M. M., Zakhidov Z. T., Baranov A. V. [et al.] Diagnosis and treatment of hangren Furnie (practical experience). Laser Medicine. 2018;22(2):39-42. https://doi.org/10.37895/2071-8004-2018-22-2

15. Novoshinov G. V., Sheremeteva A. A., Starchenkova L. P. Fournier Gangrene in a 1 Month old child. Russian Journal of Pediatric Surgery.2016;20(1):51-52 https://doi.org/10.18821/1560-9510-2016-20-21-51-52

16. Nickolsky V. I., Sergatsky K. I., Klimashevich A. V., Ogorodnik E. V. Rare causes of acute purulentinflammatory lesions of pararectal tissue and Fournier's gangrene. Pirogov Russian Journal of Sergery. - Khirurgiya. 2020;(2):68-73 https://doi.org/10.17116/hirurgia202002168

17. Privolnev V. V., Zabrosaev V. S Danilenkov N. V. Fournier's gangrene (Review). Vestnik of Smolensk State Medical Academy. - Vestnik Smolenskoj gosudarstvennoj medicinskoj akademii. 2014;13(3):47-55.

18. Prohorov A. V. Fournier's gangrene: modern approaches to treatment (literature review). Experimental and Clinical Urology. 2016;(2):106-117.

https://doi.org/10.29188/2222-8543

19. Prokhorov A. V. Experience of Furnier's gangrene clinical diagnostics. Kazan Medical Journal. 2016;97(1):159-162. https://doi.org/10.17750/KMJ2016-159

20. Priyma O. B. Treatment of patients with gangrene Fournier. Grekov's Bulletin of Surgery. 2017;176(1):76-79 https://doi.org/10.24884/0042-4625-2017-176-1-76-79

21. Prokhorov A. V. The modern view of Fournier gangrene. Pacific Medical Journal. 2017:1:5-9.

https://doi.org/10.17238/PmJ1609-1175.2017.1.5-9

22. Prokhorov A. V. Fournier's Gangrene: the Criteria for Diagnosis, Prognostic Factors, Complications and Mortality. Journal of Experimental and Clinical Surgery. 2017;10:2:154-164.

https://doi.org/10.18499/2070-478X-2017-10-2-154-164

23. Prokhorov A. V. Fournier's gangrene. Clinical and laboratory picture (literature review). Experimntal and clinical urology. 2016;1:78-89. https://doi.org/10.29188/2222-8543

\section{About authors:}

Ryzhkov Valery Vladimirovich, MD, DMSc, Professor, Head of the Department of obstetrics and gynecology of the further vocational education; tel.: +78652554331, +79187722165; e-mail: stavrisk@yandex.ru; https://orcid.org/0000-0002-0694-9984

Gasparyan Susanna Artashesovna, MD, DMSc. Professor, Professor of the Department of urology, pediatric urology-andrology, obstetrics and gynecology of the further vocational education;

tel.: +79624019121; e-mail: Prof-Gasp55@yandex.ru; https://orcid.org/0000-0001-8284-8117

Derevyanko Tatyana Igorevna, MD, DMSc, Head of the Department of urology, pediatric urology-andrology, obstetrics and gynecology, of the further vocational education; tel.: +78652554331, 904832; e-mail: stavrisk@yandex.ru; https://orcid.org/0000-0003-1659-319X

Kopylov Anatoly Vasilyevich, CMSc, Associate Professor, Head of the Stavropol Regional Forensis Medical Bureau, Head of Forensic Medicine and Law Department with a course of further vocational education, Honored Doctor of the Russian Federation; tel.: +78652260132, +78652428771; e-mail: nurse@stgmu.ru; https://orcid.org/0000-0003-3793-1370 
Papikova Karina Aleksandrovna, CMSc, Associate Professor of the Department of urology, pediatric urology-andrology, obstetrics and gynecology of the further vocational education;

tel.: +79034185115; e-mail: kpapikova@gmail.com; https://orcid.org/0000-0002-7943-9432

Pydra Ants Reinovich, CMSc, Assistant of the Department of obstetrics and gynecology;

tel.: +79624115060; e-mail: antspydra@mail.ru

Pivovarova Nadezhda Ivanovna, Head of the Department of the bacteriological laboratory;

tel.: +79624326445; e-mail: npivovarova.50.@.com

Gordeeva Larisa Petrovna, Head of the Pathoanatomical Department; tel.: +79034163528

(C) Group of authors, 2021

UDC 616.391-04.71-053.32

DOI - https://doi.org/10.14300/mnnc.2021.16051

ISSN - 2073-8137

\title{
HYPOVITAMINOSIS D AND OSTEOPENIA OF PRETERM INFANTS: RISK FACTORS AND MECHANISMS OF FORMATION
}

\author{
Klimov L. Ya. ${ }^{1}$, Petrosyan M. A. 1, 2, Verisokina N. E. 1, 2, Kuryaninova V. A. ${ }^{1,3}$, \\ Atanesyan R. A. ${ }^{1}$, Bobryshev D. V. ${ }^{1}$, Kirienko O. S. ${ }^{1,4}$, Sarieva E. M. ${ }^{4}$ \\ 1 Stavropol State Medical University, Russian Federation \\ 2 Regional Clinical Perinatal Center, Stavropol, Russian Federation \\ ${ }^{3}$ International medical center "SOGAZn, Saint Petersburg, Russian Federation \\ ${ }^{4}$ Stavropol Regional Clinical Perinatal Center № 1, Russian Federation
}

\section{ГИПОВИТАМИНОЗ D И ОСТЕОПЕНИЯ НЕАОНОШЕННЫХ АЕТЕЙ: ФАКТОРЫ РИСКА И МЕХАНИЗМЫ ФОРМИРОВАНИЯ}

\author{
А. Я. КАимов 1, М. А. Петросян 1, 2, Н. Е. Верисокина 1, 2, В. А. Курьянинова 1, 3 , \\ Р. А. Атанесян ${ }^{1}$, А. В. Бобрышев ${ }^{1}$, О. С. Кириенко 1, 4, Э. М. Сариева ${ }^{4}$ \\ 1 Ставропольский госуАарственный меАицинский университет, \\ Российская ФеАерация \\ 2 Краевой кАинический перинатальный центр, Ставрополь, \\ Российская ФеАерация \\ ${ }^{3}$ МежАунароАный МеАицинский центр «СОГАЗ», Санкт-Петербург, \\ Российская ФеАерация \\ ${ }^{4}$ Ставропольский краевой кАинический перинатальный центр № 1, \\ Российская Фелерация
}

\begin{abstract}
The article presents a literature review on the effect of vitamin D deficiency on the body of premature newborns. According to the results of numerous studies, insufficient intake of vitamin D in the fetus increases the risk of developing bronchopulmonary dysplasia, lower respiratory tract infections, and neonatal sepsis. There is evidence that hypovitaminosis $D$ negatively affects physical and neuropsychic development. One of the most important biological effects of vitamin D, namely its participation in the regulation of phosphorus-calcium metabolism and bone remodeling, is discussed. The mechanisms of the influence of parathyroid hormone (PTH) and calcitonin (CT) on the regulation of phosphorus-calcium homeostasis are also described. Increasing the survival rate of extremely low birth weight and very low birth weight infants increases the incidence of pediatricians and neonatologists with diseases such as osteopenia - a metabolic bone disease of preterm infants, characterized by impaired bone mineralization due to a lack of vitamin D, calcium and phosphorus. The review examines the causes, clinical manifestations, diagnosis, treatment and prevention of this disease.
\end{abstract}

Keywords: vitamin D, vitamin D deficiency, preterm neonate, parathyroid hormone, calcitonin, osteopenia of preterm neonates

Обзор посвящен влиянию дефицита витамина D на организм детей, рождённых раньше срока. Согласно результатам многочисленных исследований, недостаточное поступление в организм плода витамина D повышает риск развития бронхолёгочной дисплазии, инфекций нижних дыхательных путей, а также неонатального сепсиса. Имеются данные, подтверждающие негативное влияние гиповитаминоза D на физическое и нервно-психическое развитие. Обсуждается один из важнейших биологических эффектов витамина $\mathrm{D}$, а именно - его участие в регуляции фосфорно-кальциевого обмена и ремоделировании костной ткани. Также описаны механизмы влияния паратиреоидного гормона (ПТГ) и кальцитонина (КT) на регуляцию фосфорно-кальциевого гомеостаза. Повышение выживаемости новорожденных с экстремально низкой массой тела и очень низкой массой тела увеличивает частоту 